\title{
Vermikompost ile Birlikte Verilen Potasyum ve Fosforun Adsorbsiyonu Üzerine Bir Araştırma ${ }^{1}$
}

\author{
Nuri Burak Aslantekin², Nuray Mücellâ Müftüoğlu ${ }^{3 *}$ \\ Geliş / Received: 07/03/2020 \\ Revize / Revised: 30/07/2020 \\ Kabul / Accepted: 05/08/2020 \\ ÖZ \\ Yurtdışında ve ülkemizde yapılan bazı çalışmalar göz önünde bulundurulduğunda, vermikompostun bitki verimi \\ üzerinde etkili olduğu saptanmıştır. Ancak vermikompost kullanımından dolayı fosfor $(\mathrm{P})$ ve potasyum $(\mathrm{K})$ \\ elementlerinin tutunmaları konusunda çalışma bulunmamaktadır. Denemede, organik bir madde olan \\ vermikompostun $\mathrm{P}$ ve $\mathrm{K}$ elementlerini tutması üzerindeki etkisi araştırılmıştır. Deneme, iki bağımsız deneme \\ şeklinde kurulmuş olup, $\mathrm{P}$ ve $\mathrm{K}$ elementlerinin tutunabilirliği takip edilmiştir. Denemede; vermikompost aynı \\ dozda (1000 kg/da), P elementi $\left(0,4,8,12,16\right.$ ve $\left.20 \mathrm{~kg} \mathrm{P}_{2} \mathrm{O}_{5} / \mathrm{da}\right)$ ve $\mathrm{K}$ elementi $(0,10,20,30,40$ ve $50 \mathrm{~kg}$ \\ $\mathrm{K}_{2} \mathrm{O} / \mathrm{da}$ ) dozlarında kullanılmış ve 15 gün ara ile 6 yıkamaya tabi tutulmuştur. Perlit ortamına katılan \\ vermikompost ile artan $\mathrm{P}_{2} \mathrm{O}_{5}$ ve $\mathrm{K}_{2} \mathrm{O}$ uygulamaları incelendiğinde yıkanan $\mathrm{P}_{2} \mathrm{O}_{5}$ ve $\mathrm{K}_{2} \mathrm{O}$ miktarının 6 yıkama \\ sonucunda düzenli olarak ortama katılan miktarları arttıkça yıkanan miktarının da arttığı saptanmıştır. Fosforda \\ en fazla yıkanma $4 \mathrm{kgP}_{2} \mathrm{O}_{5} /$ da düzeyinde (\%45.2), en düşük yıkanma ise $12 \mathrm{kgP}_{2} \mathrm{O}_{5} /$ da düzeyinde (\%32.2) \\ bulunmuştur. Potasyumda ise en fazla yıkanma $50 \mathrm{kgK}_{2} \mathrm{O} / \mathrm{da}$ düzeyinde (\%66.8), en az yıkanma ise 10 \\ $\mathrm{kgK}_{2} \mathrm{O} /$ da düzeyinde (\%43.9) tespit edilmiştir.
}

\footnotetext{
1Bu çalışma Nuri Burak Aslantekin tarafından, Çanakkale Onsekiz Mart Üniversitesi, Fen Bilimleri Enstitüsü, Toprak Bilimi ve Bitki Besleme Anabilim Dalında yapılan Yüksek Lisans Tezinin bir kısmını kapsamakta olup Ankara'da 12-15 Temmuz 2018 tarihleri arasında yapılan Uluslararası Avrasya Doğal Beslenme ve Sağlıklı Yaşam Zirvesi'nde sunulu, özet bildiri olarak yer almıştır.

2İletişim: burak-546@hotmail.com (https://orcid.org/0000-0002-0156-9130)

Toprak Bilimi ve Bitki Besleme Bölümü, Çanakkale Onsekiz Mart Üniversitesi, Terzioğlu Yerleşkesi, 17100 Çanakkale 3*Sorumlu yazar iletişim: mucella@comu.edu.tr (https://orcid.org/0000-0001-6065-029X)

Toprak Bilimi ve Bitki Besleme Bölümü, Çanakkale Onsekiz Mart Üniversitesi, Terzioğlu Yerleşkesi, 17100 Çanakkale
} 


\title{
A Study on the Adsorption of Potassium and Phosphorus Given Together with Vermicompost
}

\begin{abstract}
Considering some studies conducted previously in Turkey and abroad, vermicompost was found to be effective on plant yield. However, due to the use of vermicompost, there are no studies on the adsorption of phosphorus (P) and potassium (K) elements. In the experiment, the effects of vermicompost, an organic fertilizer, on the retention of $\mathrm{P}$ and $\mathrm{K}$ elements were investigated. The experiment was established as 2 independent trials and the adsorption of $\mathrm{P}$ and $\mathrm{K}$ was followed. In experiments, vermicompost in the same dose $\left(10000 \mathrm{~kg} \mathrm{ha}^{-1}\right)$, the dosages of P element $\left(0,40,80,120,160\right.$ and $\left.200 \mathrm{~kg} \mathrm{P}_{2} \mathrm{O}_{5} \mathrm{ha}^{-1}\right)$, K element $(0,100,200,300,400$ and $500 \mathrm{~kg}$ $\mathrm{K}_{2} \mathrm{O}$ ha $^{-1}$ ) and 6 washings with 15 days interval was applied. When increased phosphorus and potassium applications were examined with vermicompost added to perlite medium, it was found that the amount of $\mathrm{P}_{2} \mathrm{O}_{5}$ and $\mathrm{K}_{2} \mathrm{O}$ washed increased as the amount added regularly to the medium increased as a result of 6 washings. The highest washing at $\mathrm{P}_{2} \mathrm{O}_{5}$ was found at $40 \mathrm{~kg} \mathrm{ha}^{-1}(45.2 \%)$ and the lowest washing at $120 \mathrm{~kg} \mathrm{ha}^{-1}(32.2 \%)$. In potassium, the highest washing was found at $500 \mathrm{kgK}_{2} \mathrm{O} \mathrm{ha}^{-1}(66.8 \%)$ and the least washing was found at $100 \mathrm{~kg}$ $\mathrm{K}_{2} \mathrm{O} \mathrm{ha}^{-1}(43.9 \%)$.
\end{abstract}




\section{GİRIS}

Dünya nüfus artış hızı ilk çağlarda yavaş olmasına rağmen son birkaç yüzyılda bu hızın oransal olarak arttığı görülmektedir. İnsanlar başlangıçta balıkçılıkla, toplayıcılıkla, avcılıkla geçindiklerinden küçük insan grupları için geniş alanlara gereksinim duyuluyordu. Daha sonra yerleşik yaşama geçilmesiyle tarımla uğraşılması, hayvanların evcilleştirilmesi nedeniyle daha küçük alanlar yeterli olmuştur. Ancak günümüzde tarım ve tıp alanındaki ilerlemeler, sanayi devriminin etkileri ile dünya nüfusunda hızlı artışlar görülmektedir. Nüfusun hızla artışı tarımda küçük alanlardan fazla ürün alınma gereğini doğurmuş, bu ise kimyasal gübrelerin devreye girmesine neden olmuştur. Kimyasal gübrelerin aşırı düzeyde ve bilinçsizce kullanımı yeraltı ve yer üstü tatlı su kaynaklarının kirlenmesine neden olmuştur. Kirlenmenin insan sağlı̆̆ üzerindeki olumsuz etkisini azaltmak amacıyla son yıllarda; konvansiyonel tarımın yetiştiricilikteki payını azaltmak için iyi tarım, organik tarım gibi sistemler üzerinde yoğun çalışmalar yapılmaktadır.

Ülkemizde kullanımı yaygın olmasa da solucanlar tarafından üretilen organik bir madde olan vermikompost dünya çapında birçok ülke tarafından kullanılmakta olup en önemli etkisi toprak biyolojik özellikleri üzerine olmakta, içerisinde yer alan yararlı mikroorganizmalar bitkinin kök bölgesine yerleşerek çeşitli antibiyotik, enzim ve bitki gelişim düzenleyicileri salgılamakta, böylece bitkinin toprak kökenli hastalığa neden olan organizmalardan korunmasını, toprakta yarayışsız konumdaki organik bağlı besin elementlerinden faydalanmasını, bitkinin kök, sürgün gelişimi ve meyve tutumuna yardımcı olmaktadır [23]. Kompostlamada solucan kullanmanın faydası, sadece bitkisel üretimi arttırması değil aynı zamanda ortamda hastalık etmeni olan organizmaları da azaltması, bitkisel üretimde toprakların sürdürülebilir olmasına yönelik pek çok eksikliğini ortadan kaldırması, toprağa sağladığı biyolojik, fiziksel ve kimyasal iyileşmeler sebebiyle son zamanlarda en çok tutulan organik maddelerden biri olmasıdır [22]. Vermikompost çeşitli özellikteki organik atıkların bazı toprak solucanları tarafından bünyelerinde sindirmeleri sırasında kompostlaştırılan, bitki besin maddeleri, mikroorganizmalar, çeşitli enzimler, organik madde, humik ve fulvik asitlerce zengin özelliklere sahip hem toprak düzenleyicisi olarak hem de aynı zamanda bitki beslemede açısından gübre olarak kullanılan organik bir madde olarak tanımlanmaktadır [8]. Organik atıklardan yararlanılması amacı ile elde edilen vermikompost, ekonomik ve sürdürülebilir bir yöntem olarak bitki büyümesini olumlu yönde artırmakta, bitki beslemede yardımcı olmakta, küçük veya orta ölçekli tarım işletmeleri için ek bir masrafa gerek kalmaksızın az miktardaki girdiler ile üretim sistemini olanaklı hale getirmektedir. Ayrıca organik tarıma geçiş sürecindeki ilk yıllarda görülen ürün düşüşünü de telafi edebilmektedir [21]. Vermikompost uygulamasının ispanak bitkisinin verim, verim özellikleri, toprak verimlilik özellikleri üzerine kontrole oranla önemli artışlar gösterdiği, özellikle bitkinin demir $(\mathrm{Fe})$ ve toprağın kalsiyum (Ca) miktarı üzerine $200 \mathrm{~kg} / \mathrm{da}$ vermikompost uygulamasının en iyi sonucu verdiği, toprak reaksiyonu $(\mathrm{pH})$, suda çözünebilir tuz $(\mathrm{EC})$ ve organik madde değerlerinin tüm uygulamalarda kontrole göre artı̧̧lar gösterdiği belirlenmiştir [19]. Kompostun tarımda kullanılma uygulamaları ülkemiz için yeni sayılabilecek niteliktedir. Organik atıkların normal olgunlaştırma yöntemleri ile kompost şekline getirilmesinin yanında, toprak solucanlarının ilave edilmesi ile vermikompost elde edilerek değerlendirilmesi de mümkündür [4]. Fosfor adsorpsiyonu ve fiksasyonu üzerine yapılan çalışmada toprak örneğine P32 uygulanarak topraklarda kil, değişebilir $\mathrm{Ca}$, magnezyum $(\mathrm{Mg})$ miktarının fosfor adsorpsiyonu ve fiksasyonu üzerinde pozitif etkileri olduğu ancak kum miktarı ve ortamda var olan fosforun olumsuz etkileri olduğu sonucuna ulaşılmıştır [6]. Bitki ihtiyaç duyduğu fosforun önemli bir bölümünü toprak çözeltisinden ve az bir kısmını da doğrudan toprağın katı kısmından almakta, toprak solüsyonunda azalan fosfor yerine katı fazdan sağlanan fosforla denge kurulmakta, denge toprak çözeltisi aleyhine bozulduğu anda bitkilerin fosfor gereksinimlerini karşılayamadıkları belirtilmiştir [9]. Özellikle kurak ve yarı kurak iklim özelliklerine sahip alanlardaki yer alan topraklarda fosfor adsorpsiyonu ile toprakların fiziksel ve kimyasal özellikleri arasındaki etkileşimin çok yönlü olmasının adsorbsiyonun açıklanmasını zorlaştırdığı, ancak toprakların kireç içeriği, kil tipi ve Fe oksit miktarlarının fosfor adsorpsiyonu üzerinde etkili faktörler olduğu belirtilmiştir [12]. Artan seviyelerde sıvı TKİ-Hümas ve fosfor uygulamalarının fasulye bitkisinin verim ve kalite unsurları üzerine etkileri belirlemek amacıyla tarla şartların yürütülen bir çalışmada TKİ-Hümas $0,4,8,12 \mathrm{~L}$ /da ve diamonyum fosfat gübresi kaynaklı fosfor $0,5.0,7.5$ ve $10 \mathrm{~kg} \mathrm{P}_{2} \mathrm{O}_{5} /$ da kullanılmış, araştırma sonuçlarına göre fasulye bitkisinin verimi üzerine hem TKİ-Hümas hem de fosfor uygulamalarının etkisi istatistiki bakımdan önemli bulunmuş, bitkilerin beslenmesi, ekonomik olması ve verimin artırılması bakımından $12 \mathrm{~L} /$ da TKİ-Hümas ve $5 \mathrm{~kg} \mathrm{P}_{2} \mathrm{O}_{5} /$ da kombinasyonu önerilebileceği belirtilmiştir [13]. Ortamda organik maddenin bulunmasının $\mathrm{P}$ adsorpsiyonunu artıran bir etmen olduğu dolayısı ile organik maddenin fosfor adsorbe etme kabiliyetinin bulunduğunu gösterdiği belirtilmektedir [24]. 
Toprağa gübre olarak ilave edilen veya toprakta değişik şekillerde bulunmakta olan potasyumun, toprak ve çevre koşullarına göre elverişli şekle veya fikse olarak elverişsiz şekle dönüştüğü, potasyum fiksasyonunun diğer bazı katyonik besin elementlerinin toprakta tutulmasından farklı bir şekilde açıklanmaya gereksinim olduğu, fikse olan potasyumla katyon değişim kapasitesinin, değişebilen ve güçlükle değişebilen potasyum miktarları arasında istatistiksel olarak önemli pozitif ilişkiler olduğu belirtilmiştir [18]. Bitki besin elementleri içerisinde önemli bir etkiye sahip olan potasyumun $\mathrm{pH}$ ile ilişkisinin tam olarak aydınlatılmış sayılamayacağını ancak potasyumun asit ortamlarda $\mathrm{Fe}$, alüminyum $(\mathrm{Al})$ ve $\mathrm{H}$ iyonları ile rekabeti sonucunda fiksasyonunun azaldığını, bunun aksine alkalin topraklarda ise daha fazla fiksasyona uğradığı belirtilmektedir [5]. Potasyumun en önemli kaynaklarını denizsel evaporitler oluşturur ve üretiminin $\% 90$ 'ı gübre sanayinde kullanılmaktadır. Magmatik, sedimanter ve metamorfik kökenli pek çok kayaç içindeki silikatlı minerallerin yapısında değişen oranlarda yer almaktadır. Bu değişiklik, ana maddenin yaşı, mineral çeşidi ve iklim koşullarından kaynaklanmaktadır. Kumtaşı ya da kuvartzit üzerinde oluşmuş kaba bünyeli toprakların K içeriği, potasyumlu mineral içeren kayalar üzerinde oluşan ince bünyeli toprakların $\mathrm{K}$ içeriğinden oldukça düşüktür. Ayrıca bol miktarda yağış alan bölgelerde yıkanmanın $\mathrm{K}$ olması nedeniyle topră̆ın $\mathrm{K}$ içeriği düşmektedir [10]. Potasyum litosferin yaklaşık \%2.5ini oluş̧urmaktadır. Potasyum bitkinin ihtiyaç duyduğu elementler arasında azottan sonra en fazla alınan besin elementidir. Potasyum içerikleri topraklarda büyük değişkenlik (\%0.04-3.00) göstermektedir [3]. Toprakların toplam K içeriği, çoğunlukla bitkilerin bir gelişme mevsimi boyunca absorbe ettiği miktarın birçok katı olduğu halde, çoğu durumda, bu toplam potasyumun ancak çok küçük bir bölümü bitkilere yarayışlıdır. Bitki gelişimi için zorunlu olan potasyum elementinin, bitkilerdeki konsantrasyonu tipik olarak kuru maddenin \%0.5-6.0'sı arasında değişmekle birlikte, bazı durumlarda daha yüksek oranlarda da bulunabilir. Bitki hücrelerinde en fazla bulunan katyondur ve bitki kuru ağırlığının \%10'unu içerecek şekilde bulunabilir [20].

Yapılan bu çalışma ile organik bir madde olan ve kullanımı gittikçe artan vermikompostun ilave edildiği ortamlarda bitki için çok önemli olan $\mathrm{P}$ ve $\mathrm{K}$ elementlerinin tutunmalarını nasıl etkilendiğinin belirlenmesi amaçlanmıştır. Farklı gübre uygulamalarının vermikompost üzerine farklı dozlarda uygulamasıyla yürütülen çalışmada, farklı gübre kaynaklarının vermikompost tutulma parametreleri üzerinde etkinliğinin ortaya konulması amacıyla yürütülmüştür.

\section{MATERYAL VE YÖNTEM}

Denemede ortam olarak nötr reaksiyonlu süper iri tarım perliti, organik madde olarak vermikompost, fosfor kaynağı olarak triplesüper fosfat (TSP, $\% 42 \mathrm{P}_{2} \mathrm{O}_{5}$ ) gübresi, potasyum kaynağı olarak potasyum sülfat (PS, $\% 51 \mathrm{~K}_{2} \mathrm{SO}_{4}$ ) gübresi, yıkama işlemlerinde saf su kullanılmıştır.

Denemede kullanılan vermikompostun reaksiyonu 6.60, suda çözünebilir tuz değeri $2.60 \mathrm{dS} / \mathrm{m}$, suda çözünebilir potasyum $6683.93 \mathrm{mg} / \mathrm{kg}$, toplam potasyum $10137.39 \mathrm{mg} / \mathrm{kg}$, suda çözünebilir fosfor $193.62 \mathrm{mg} / \mathrm{kg}$, toplam fosfor ise $3896.96 \mathrm{mg} / \mathrm{kg}$ değerindedir.

Deneme, yarı kontrollü serada, 6 farklı doz, 4 tekerrür olmak üzere fosfor ve potasyum için iki ayrı deneme şeklinde toplam 48 saksı ile tesadüf parseli faktöriyel deneme desenine göre kurulmuştur. Saksılara hacim esasına göre $3.5 \mathrm{~L}$ perlit doldurulmuş ve hepsine $1000 \mathrm{~kg} / \mathrm{da}$ hesabı ile vermikompost ilave edilip üst kısmı homojen bir şekilde karıştırılarak saksı içeriği saf su ile doyurulmuştur.

Marul bitkisinde vermikompost uygulamasının yaygın olması nedeni ile bu bitkinin besin maddesi istekleri dikkate alınmıştır. Marul bitkisinin yetiştirilmesi için10-12 $\mathrm{kg} \mathrm{P}_{2} \mathrm{O}_{5}$ ve $18-20 \mathrm{~kg} \mathrm{~K}_{2} \mathrm{O}$ verilmesinin yeterli olduğu belirtilmiş̧ir [7]. Bu nedenle perlit ve vermikompost bulunan saksılara fosfor uygulaması için TSP gübresi $0,4,8,12,16,20 \mathrm{~kg} \mathrm{P}_{2} \mathrm{O}_{5} / \mathrm{da}$, potasyum uygulaması için $\mathrm{K}_{2} \mathrm{SO}_{4}$ gübresi 0, 10, 20, 30, 40, $50 \mathrm{~kg} \mathrm{~K}_{2} \mathrm{O} / \mathrm{da}$ olacak şekilde saf suda çözülerek uygulanmıştır.

Potasyum ve fosforun saksılar içerisinde vermikomposta tutunmaları için iki hafta beklendikten sonra yıkama başlamış ve iki hafta aralıklarla yapılan 1., 2., 3. yıkamalarda $300 \mathrm{~mL}$ saf su ve 4., 5., 6, yıkamalarda 250 $\mathrm{mL}$ saf su ile yavaş yavaş doyularak saksı altlıklarında biriken örneklerin taşmasına izin verilmeksizin alınmış, mezür ile ölçülmüş, balon jojelere ve pet şişelere aktarılmıştır. İki hafta aralıklarda alınan örnekler aynı gün içerisinde laboratuvara getirilmiştir. Laboratuvara getirilen örnekler filtre kâğıdından süzülerek homojen hale 
getirilip balon jojelere aktarılıp analizlerin yapılacağı zamana kadar buzdolabında saklanmıştır. Fosfor analizi, denemeden alınan süzükler bulunan fosfor miktarına göre oluşan mavi renk yoğunluğunun spektrometrede standart çözeltilerle karşılaştırılması esasına göre, potasyum analizi, denemeden alınan süzüklerdeki potasyum miktarlarının alev fotometresi ile belirlenmesi esasına göre tespit edilmiştir [14].

Deneme sonucunda elde edilen veriler MINITAB 18.0 istatistik paket programı kullanılarak değerlendirilmiştir. Veriler tesadüf parselleri deneme desenine göre varyans analizine tabi tutularak F testi ile önemlilik kontrolleri yapılmış, özelliklere ait ortalama değerlerin çoklu karşılaştırılması ise LSD çoklu karşılaştırma testi ile yapılmıştır.

\section{BULGULAR}

\section{A. Fosfor yıkama bulguları}

Perlit ortamına ilave edilen vermikompost ve artan dozdaki fosfor uygulamalarının yıkanan fosfor miktarlarına olan etkisi Tablo 1'de verilmiştir.

Tablo 1. Ortamdan Y1kanan Fosfor Miktarları

\begin{tabular}{|c|c|c|c|c|c|c|c|c|}
\hline \multirow{2}{*}{$\begin{array}{l}\text { VK } \\
\text { (kg/da) }\end{array}$} & \multicolumn{8}{|c|}{ Y1kanan $\mathrm{P}_{2} \mathrm{O}_{5}$ Miktarı (g/da) } \\
\hline & & 1. & 2. & 3. & 4. & 5. & 6. & Toplam \% \\
\hline \multirow{6}{*}{1000} & 0 & $32 \mathrm{C}$ & $331 \mathrm{~B}$ & $74 \mathrm{D}$ & $36 \mathrm{C}$ & $37 \mathrm{D}$ & $25 \mathrm{D}$ & $535 \mathrm{E}$ \\
\hline & 4 & $205 \mathrm{C}$ & $687 \mathrm{~A}$ & $360 \mathrm{CD}$ & $263 \mathrm{BC}$ & $287 \mathrm{C}$ & $206 \mathrm{CD}$ & 2009 D 45.2 \\
\hline & 8 & $410 \mathrm{BC}$ & $673 \mathrm{~A}$ & $576 \mathrm{BC}$ & $392 \mathrm{~B}$ & $386 \mathrm{C}$ & $306 \mathrm{C}$ & 2742 D 32.5 \\
\hline & 12 & $282 \mathrm{BC}$ & $542 \mathrm{AB}$ & 946 B & $1051 \mathrm{~A}$ & $684 \mathrm{~B}$ & $502 \mathrm{~B}$ & 4008 C 32.2 \\
\hline & 16 & $1129 \mathrm{~B}$ & $656 \mathrm{~A}$ & $1865 \mathrm{~A}$ & $1022 \mathrm{~A}$ & $1218 \mathrm{~A}$ & $715 \mathrm{~A}$ & 6606 B 40.2 \\
\hline & 20 & $3530 \mathrm{~A}$ & $702 \mathrm{~A}$ & 1917 A & $941 \mathrm{~A}$ & $1263 \mathrm{~A}$ & $682 \mathrm{AB}$ & 9034 A 44.2 \\
\hline $\mathrm{P}$ & & $0.000 * *$ & $0.011^{*}$ & $0.000^{* *}$ & $0.000 * *$ & $0.000 * *$ & $0.000 * *$ & $0.000 * *$ \\
\hline
\end{tabular}

VK: Vermikompost, *: \%5 düzeyinde önemli, **: \%1 düzeyinde önemli, 1.-6.: Y1kama sayıları

Perlit ortamına katılan vermikompost ve artan fosfor uygulamalarının etkilerinin görüldüğü Tablo 1 incelendiğinde, 1. yıkamada yıkanan fosfor miktarının sadece vermikompost uygulama (kontrol) dozundan elde edilen $32 \mathrm{~g} \mathrm{P}_{2} \mathrm{O}_{5} /$ da ile $20 \mathrm{~kg} \mathrm{P}_{2} \mathrm{O}_{5} /$ da verilen uygulama dozundan elde edilen $3530 \mathrm{~g} \mathrm{P}_{2} \mathrm{O}_{5} / \mathrm{da}$ arasında değiştiği, düzenli olmamakla birlikte ortama katılan fosfor miktarı arttıkça yıkanan fosfor miktarında da artış olduğu, 1 . yıkama sonunda ortamdan yıkanan fosfor miktarlarına etkisinin \%1 düzeyinde önemli olduğu görülmektedir.

2. yıkamada yıkanan fosfor miktarının kontrol dozundan elde edilen $331 \mathrm{~g} \mathrm{P}_{2} \mathrm{O}_{5} / \mathrm{da}$ ile $20 \mathrm{~kg} \mathrm{P}_{2} \mathrm{O}_{5} / \mathrm{da}$ verilen uygulama dozundan elde edilen $702 \mathrm{~g} \mathrm{P}_{2} \mathrm{O}_{5} / \mathrm{da}$ arasında değiştiği, düzenli olmamakla birlikte ortama katılan fosfor miktarı arttıkça yıkanan fosfor miktarında artış olduğu, 2. yıkama sonunda ortamdan yıkanan fosfor miktarlarına etkisinin $\% 5$ düzeyinde önemli olduğu tespit edilmiştir.

3. yıkamada yıkanan fosfor miktarının kontrol dozundan elde edilen $74 \mathrm{~g} \mathrm{P}_{2} \mathrm{O}_{5} / \mathrm{da}$ ile $20 \mathrm{~kg} \mathrm{P}_{2} \mathrm{O}_{5} / \mathrm{da}$ verilen uygulama dozundan elde edilen $1917 \mathrm{~g} \mathrm{P}_{2} \mathrm{O}_{5} /$ da arasında değiştiği, düzenli olarak ortama katılan fosfor miktarı arttıkça yıkanan fosfor miktarında artış olduğu, 3. yıkama sonunda ortamdan yıkanan fosfor miktarlarına etkisinin \%1 düzeyinde önemli olduğu belirlenmiştir. 
4. yıkamada yıkanan fosfor miktarının kontrol dozundan elde edilen $36 \mathrm{~g} \mathrm{P}_{2} \mathrm{O}_{5} / \mathrm{da}$ ile $12 \mathrm{~kg} \mathrm{P}_{2} \mathrm{O}_{5} / \mathrm{da}$ verilen uygulama dozundan elde edilen $1051 \mathrm{~g} \mathrm{P}_{2} \mathrm{O}_{5} /$ da arasında değiştiği, 4. yıkamada fosforun en fazla yıkandığı dozun $12 \mathrm{~kg} \mathrm{P}_{2} \mathrm{O}_{5} /$ da dozu olduğu, 4. yıkama sonunda ortamdan y1kanan fosfor miktarlarına etkisinin $\% 1$ düzeyinde önemli olduğu saptanmıştır.

5. yıkamada yıkanan fosfor miktarının kontrol dozundan elde edilen $37 \mathrm{~g} \mathrm{P}_{2} \mathrm{O}_{5} /$ da ile $20 \mathrm{~kg} \mathrm{P}_{2} \mathrm{O}_{5} / \mathrm{da}$ verilen uygulama dozundan elde edilen $1263 \mathrm{~g} \mathrm{P}_{2} \mathrm{O}_{5} / \mathrm{da}$ arasında değiştiği, düzenli olarak ortama katılan fosfor miktarı arttıkça yıkanan fosfor miktarında artış olduğu, 5. yıkama sonunda ortamdan yıkanan fosfor miktarlarına etkisinin \%1 düzeyinde önemli olduğu bulunmuştur.

6. yıkamada yıkanan fosfor miktarının kontrol dozundan elde edilen $25 \mathrm{~g} \mathrm{P}_{2} \mathrm{O}_{5} / \mathrm{da}$ ile $16 \mathrm{~kg} \mathrm{P}_{2} \mathrm{O}_{5} / \mathrm{da}$ verilen uygulama dozundan elde edilen $715 \mathrm{~g} \mathrm{P}_{2} \mathrm{O}_{5} /$ da arasında değiştiği, 6. yıkamada fosforun en fazla yıkandığ dozun $16 \mathrm{~kg} \mathrm{P}_{2} \mathrm{O}_{5} / \mathrm{da}$ dozu olduğu, 6. yıkama sonunda ortamdan yıkanan fosfor miktarlarına etkisinin $\% 1$ düzeyinde önemli olduğu görülmektedir.

Perlit ortamına ilave edilen vermikompost ve artan dozdaki fosfor uygulamalarının toplam 6 yıkama sonucunda kontrol dozundan elde edilen $535 \mathrm{~g} \mathrm{P}_{2} \mathrm{O}_{5} /$ da ile $20 \mathrm{~kg} \mathrm{P}_{2} \mathrm{O}_{5} /$ da verilen uygulama dozundan elde edilen $9034 \mathrm{~g} \mathrm{P}_{2} \mathrm{O}_{5} / \mathrm{da}$ arasında değiştiği, düzenli olarak ortama katılan fosfor miktarı arttıkça yıkanan fosfor miktarında da artış olduğu, toplam 6 yıkama sonunda ortamdan yıkanan fosfor miktarlarına etkisinin \% 1 düzeyinde önemli olduğu tespit edilmiştir.

\section{B. Potasyum yıkama bulguları}

Perlit ortamına ilave edilen vermikompost ve artan dozdaki potasyum uygulamalarının yıkanan potasyum miktarlarına olan etkisi Tablo 2'de verilmiştir.

Tablo 2. Ortamdan Y1kanan Potasyum Miktarları

\begin{tabular}{|c|c|c|c|c|c|c|c|c|}
\hline \multirow{2}{*}{$\begin{array}{l}\text { VK } \\
\text { (kg/da) }\end{array}$} & \multirow{2}{*}{$\mathrm{K}_{2} \mathrm{O}(\mathrm{kg} / \mathrm{da})$} & \multicolumn{7}{|c|}{ Y1kanan $\mathrm{K}_{2} \mathrm{O}$ Miktarı (g/da) } \\
\hline & & 1. & 2. & 3. & 4. & 5. & 6. & Toplam \% \\
\hline \multirow{6}{*}{1000} & 0 & $519 \mathrm{D}$ & $37 \mathrm{~B}$ & $98 \mathrm{C}$ & $94 \mathrm{D}$ & $98 \mathrm{E}$ & $92 \mathrm{C}$ & $938 \mathrm{E}$ \\
\hline & 10 & $4573 \mathrm{CD}$ & $46 \mathrm{~B}$ & $1150 \mathrm{BC}$ & $873 \mathrm{D}$ & $1001 \mathrm{DE}$ & $273 \mathrm{BC}$ & 7916 D 43.9 \\
\hline & 20 & 8847 BC & $43 \mathrm{~B}$ & $2525 \mathrm{~B}$ & $2114 \mathrm{C}$ & $2526 \mathrm{CD}$ & $1033 \mathrm{~B}$ & 17089 C 61.0 \\
\hline & 30 & $7362 \mathrm{BCD}$ & $73 \mathrm{AB}$ & $4981 \mathrm{~A}$ & $4029 \mathrm{~B}$ & $3587 \mathrm{BC}$ & $2220 \mathrm{~A}$ & $22251 \mathrm{C} 58.5$ \\
\hline & 40 & $12207 \mathrm{~B}$ & $157 \mathrm{~A}$ & $5271 \mathrm{~A}$ & $5111 \mathrm{AB}$ & $5358 \mathrm{AB}$ & $2846 \mathrm{~A}$ & 30950 В 64.5 \\
\hline & 50 & $18108 \mathrm{~A}$ & $170 \mathrm{~A}$ & $6318 \mathrm{~A}$ & $5458 \mathrm{~A}$ & $6442 \mathrm{~A}$ & $2285 \mathrm{~A}$ & 38781 A 66.8 \\
\hline $\mathrm{P}$ & & $0.001 * *$ & $0.022 *$ & $0.000 * *$ & $0.000^{* *}$ & $0.000^{* *}$ & $0.000 * *$ & $0.000^{* *}$ \\
\hline
\end{tabular}

VK: Vermikompost, *: \%5 düzeyinde önemli, **: \%1 düzeyinde önemli, 1.-6.: Yıkama sayıları

Perlit ortamına katılan vermikompost ve artan potasyum uygulamalarının etkilerinin görüldüğ̈ Tablo 2 incelendiğinde, 1. yıkamada yıkanan potasyum miktarının kontrol dozundan elde edilen $519 \mathrm{~g} \mathrm{~K}_{2} \mathrm{O} / \mathrm{da}$ ile $50 \mathrm{~kg}$ $\mathrm{K}_{2} \mathrm{O}$ /da verilen uygulama dozundan elde edilen $18108 \mathrm{~g} \mathrm{~K}_{2} \mathrm{O} / \mathrm{da}$ arasında değiştiği, düzenli olmamakla birlikte ortama katılan potasyum miktarı arttıkça yıkanan potasyum miktarında artış olduğu, 1. yıkama sonunda ortamdan yıkanan potasyum miktarlarına etkisinin \%1 düzeyinde önemli olduğu görülmektedir. 
2. yıkamada yıkanan potasyum miktarının kontrol dozundan elde edilen $37 \mathrm{~g} \mathrm{~K}_{2} \mathrm{O} / \mathrm{da}$ ile $50 \mathrm{~kg} \mathrm{~K}_{2} \mathrm{O} / \mathrm{da}$ verilen uygulama dozundan elde edilen $170 \mathrm{~g} \mathrm{~K} 2 \mathrm{O} / \mathrm{da}$ arasında değiştiği, düzenli olmamakla birlikte ortama katılan potasyum miktarı arttıkça yıkanan potasyum miktarında artış olduğu, 2. yıkama sonunda ortamdan yıkanan potasyum miktarlarına etkisinin \%5 düzeyinde önemli olduğu saptanmıştır.

3. yıkamada yıkanan potasyum miktarının kontrol dozundan elde edilen $98 \mathrm{~g} \mathrm{~K}_{2} \mathrm{O} / \mathrm{da}$ ile $50 \mathrm{~kg} \mathrm{~K}_{2} \mathrm{O} / \mathrm{da}$ verilen uygulama dozundan elde edilen $6318 \mathrm{~g} \mathrm{~K} \mathrm{~K}_{2} \mathrm{O} / \mathrm{da}$ arasında değiştiği, düzenli olarak ortama katılan potasyum miktarı arttıkça yıkanan potasyum miktarında artış olduğu, 3. yıkama sonunda ortamdan yıkanan potasyum miktarlarına etkisinin \%1 düzeyinde önemli olduğu belirlenmiştir.

4. yıkamada yıkanan potasyum miktarının kontrol dozundan elde edilen $94 \mathrm{~g} \mathrm{~K}_{2} \mathrm{O} / \mathrm{da}$ ile $50 \mathrm{~kg} \mathrm{~K}_{2} \mathrm{O} / \mathrm{da}$ verilen uygulama dozundan elde edilen $5458 \mathrm{~g} \mathrm{~K} 2 \mathrm{O} / \mathrm{da}$ arasında değiştiği, düzenli olarak ortama katılan potasyum miktarı arttıkça yıkanan potasyum miktarında artış olduğu, 4. yıkama sonunda ortamdan yıkanan potasyum miktarlarına etkisinin $\% 1$ düzeyinde önemli olduğu tespit edilmiştir.

5. yıkamada yıkanan potasyum miktarının kontrol dozundan elde edilen 98 g K $2 \mathrm{O} / \mathrm{da}$ ile $50 \mathrm{~kg} \mathrm{~K}_{2} \mathrm{O} / \mathrm{da}$ verilen uygulama dozundan elde edilen $6442 \mathrm{~g} \mathrm{~K} \mathrm{~K}_{2} \mathrm{O} / \mathrm{da}$ arasında değiştiği, düzenli olarak ortama katılan potasyum miktarı arttıkça yıkanan potasyum miktarında artış olduğu, 5. yıkama sonunda ortamdan yıkanan potasyum miktarlarına etkisinin \%1 düzeyinde önemli olduğu bulunmuştur.

6. yıkamada yıkanan potasyum miktarının kontrol dozundan elde edilen $92 \mathrm{~g} \mathrm{~K}_{2} \mathrm{O} / \mathrm{da}$ ile $40 \mathrm{~kg} \mathrm{~K}_{2} \mathrm{O} / \mathrm{da}$ verilen uygulama dozundan elde edilen $2846 \mathrm{~g} \mathrm{~K}_{2} \mathrm{O} / \mathrm{da}$ arasında değiştiği, 6. yıkamada potasyumun en fazla yıkandığı dozun $40 \mathrm{~kg} \mathrm{~K} 2 \mathrm{O} / \mathrm{da}$ dozu olduğu, 6. yıkama sonunda ortamdan yıkanan potasyum miktarlarına etkisinin $\% 1$ düzeyinde önemli olduğu tespit edilmiştir.

Perlit ortamına ilave edilen vermikompost ve artan dozdaki potasyum miktarının 6 yıkama sonucunda kontrol dozundan elde edilen $938 \mathrm{~g} \mathrm{~K}_{2} \mathrm{O} / \mathrm{da}$ ile $50 \mathrm{~kg} \mathrm{~K} 2 \mathrm{O} / \mathrm{da}$ verilen uygulama dozundan elde edilen $38781 \mathrm{~g}$ $\mathrm{K}_{2} \mathrm{O} /$ da arasında değiştiği, düzenli olarak ortama katılan potasyum miktarı arttıkça yıkanan potasyum miktarında da artış olduğu, toplam 6 yıkama sonunda ortamdan yıkanan potasyum miktarlarına etkisinin \%1 düzeyinde önemli olduğu belirlenmiştir.

\section{TARTIŞMA VE SONUÇ}

Perlit ortamına ilave edilen vermikompost ve artan dozda ilave edilen fosfordan yıkanan fosfor miktarının 6 yıkama sonucunda kontrol uygulamasına göre artan fosfor düzeylerine bağlı olarak arttığ

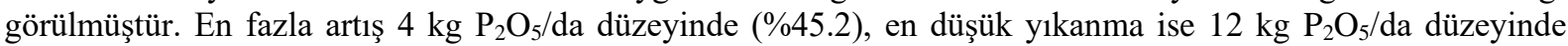
(\%32.2) bulunmuştur.

Yapılan bir çalışmada vermikompost oluşumu ve organik maddenin ayrışması sırasında ortama malonik asit, fumarik asit, süksinik asit gibi birçok organik bileşiklerin verildiğini ve böylece bitki besin maddelerinin yarayışlılığının arttığı bildirilmiştir [1]. Diğer bir çalışmada, 90 günlük inkübasyonun sonunda vermikompostun topraktaki alınabilir fosfor miktarını \%13-26 oranında artırdığı rapor edilmiştir [16]. Ayrıca vermikompostun kaya fosfatta bulunan suda çözünebilir fosfor miktarını olumlu etkilediğini bildirilmiştir [2].

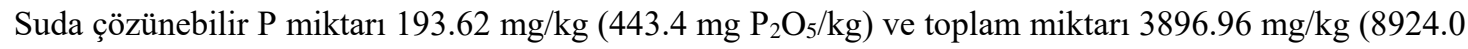
$\mathrm{mg} \mathrm{P}_{2} \mathrm{O}_{5} / \mathrm{kg}$ ) olan vermikomposttan perlit ortamına $1000 \mathrm{~kg} /$ da hesabı ile katıldığında, suda çözünebilir P miktarı $443.4 \mathrm{~g} \mathrm{P}_{2} \mathrm{O}_{5} / \mathrm{da}$ ve toplam miktar $8924.0 \mathrm{~g} \mathrm{P}_{2} \mathrm{O}_{5} /$ da olmaktadır. Denemede 6 yıkama sonunda yıkanan fosfor miktarı $535 \mathrm{~g} \mathrm{P}_{2} \mathrm{O}_{5} /$ da olarak belirlenmiştir. $\mathrm{Bu}$ durum vermikomposttaki suda çözünebilir fosforun tamamen yıkandığını, bunun yanı sıra toplam fosfordan da mineralizasyon sonucunda suda çözünebilir şekle geçen fosforun da bir kısmının (535-443.4=91.6 g/da) yıkandığg saptanmıştır.

Perlit ortamına katılan vermikompost ve $4 \mathrm{~kg} \mathrm{P}_{2} \mathrm{O}_{5} / \mathrm{kg}$ dozu ile uygulanan toplam suda çözünebilir fosforun $\left(4000+443.4=4443.4 \mathrm{~g} \mathrm{P}_{2} \mathrm{O}_{5} / \mathrm{da}\right) \% 45.2$ 'nin yıkandığı hesaplanmıştır. Bu hesaplama dikkate alınarak 8 $\mathrm{kg} \mathrm{P}_{2} \mathrm{O}_{5} / \mathrm{kg}$ dozu ile uygulanan toplam suda çözünebilir fosforun \%32.5, $12 \mathrm{~kg} \mathrm{P}_{2} \mathrm{O}_{5} / \mathrm{kg}$ dozu ile uygulanan toplam suda çözünebilir fosforun $\% 32.2,16 \mathrm{~kg} \mathrm{P} \mathrm{P}_{5} \mathrm{O}_{5} / \mathrm{kg}$ dozu ile uygulanan toplam suda çözünebilir fosforun $\% 40.2,20 \mathrm{~kg} \mathrm{P} \mathrm{O}_{5} / \mathrm{kg}$ dozu ile uygulanan toplam suda çözünebilir fosforun \%44.2 yıkandığı belirlenmiştir. Bu 
durumda 8 ve $12 \mathrm{~kg} \mathrm{P} \mathrm{P}_{2} \mathrm{O}_{5} / \mathrm{kg}$ dozunda en fazla tutunmanın gerçekleştiği daha az veya daha fazla dozlarda ise tutunmanın daha az olduğu tespit edilmiştir.

Toplam 6 yıkama sonunda yıkanan potasyum miktarının 938 g K $2 \mathrm{O} /$ da kontrol uygulaması ile $38781 \mathrm{~g}$ $\mathrm{K}_{2} \mathrm{O} / \mathrm{da}\left(50 \mathrm{~kg} / \mathrm{da} \mathrm{K}_{2} \mathrm{O}\right.$ düzeyi) arasında değiştiği, düzenli olarak ortama katılan potasyum miktarı arttıkça yıkanan potasyum miktarında da artış olduğu belirlenmiştir.

Yapılan bir çalışmada kireçli topraklara $20 \mathrm{~g} / \mathrm{kg}$ zeolit ve $20 \mathrm{~g} / \mathrm{kg}$ vermikompost uygulamış ve her iki uygulamanın da topraktaki tüm potasyum formlarını olumlu etkilediği ve ayrıca vermikompostun topraklara salınan toplam potasyumu artırdığı, vermikompost uygulamasının potasyum iyonlarının kil minerallerine (simektit) tutunmasına yardımcı olduğu rapor edilmiştir [15]. Topraklara eklenen organik artıkların toprakların alınabilir K içeriğini önemli derecede etkilediği bildirilmiştir [11, 17].

Suda çözünebilir K miktarı $6683.93 \mathrm{mg} / \mathrm{kg}\left(8020.7 \mathrm{mg} \mathrm{K} \mathrm{K}_{2} \mathrm{O} / \mathrm{kg}\right)$ ve toplam miktarı $10137.39 \mathrm{mg} / \mathrm{kg}$ (12164.8 mg $\mathrm{P}_{2} \mathrm{O}_{5} / \mathrm{kg}$ ) olan vermikomposttan perlit ortamına $1000 \mathrm{~kg} / \mathrm{da}$ hesabı ile katıldı̆̆ında, suda çözünebilir $\mathrm{K}$ miktarı $8020.7 \mathrm{~g} \mathrm{~K}_{2} \mathrm{O} /$ da ve toplam miktarı $12164.8 \mathrm{~g} \mathrm{~K}_{2} \mathrm{O} /$ da olmaktadır. Denemede 6 yıkama sonunda yıkanan potasyum miktarı $938 \mathrm{~g} \mathrm{~K}_{2} \mathrm{O}$ /da olarak belirlenmiştir, bu durum vermikomposttaki suda çözünebilir potasyumun az bir kısmının (\%11.7) yıkandı̆̆ı saptanmıştır.

Perlit ortamına katılan vermikompost ve $10 \mathrm{~kg} \mathrm{~K} 2 \mathrm{O} / \mathrm{da}$ dozu ile uygulanan toplam suda çözünebilir potasyumun $\left(10000+8020.7=18020.7 \mathrm{~g} \mathrm{~K}_{2} \mathrm{O} / \mathrm{da}\right) \% 43.9$ 'un yıkandığı hesaplanmıştır. Bu hesaplama dikkate alınarak $20 \mathrm{~kg} \mathrm{~K}_{2} \mathrm{O} /$ da dozu ile uygulanan toplam suda çözünebilir potasyumun \%61.0, $30 \mathrm{~kg} \mathrm{~K}_{2} \mathrm{O} /$ da dozu ile uygulanan toplam suda çözünebilir potasyumun \%58.5, $40 \mathrm{~kg} \mathrm{~K} \mathrm{~K}_{2} \mathrm{O} / \mathrm{da}$ dozu ile uygulanan toplam suda çözünebilir potasyumun $\% 64.5,50 \mathrm{~kg} \mathrm{~K} \mathrm{~K}_{2} \mathrm{O} / \mathrm{da}$ dozu ile uygulanan toplam suda çözünebilir potasyumun $\% 66.8$ 'inin yıkandığı belirlenmiştir. Bu durumda $10 \mathrm{~kg} \mathrm{~K}_{2} \mathrm{O} / \mathrm{kg}$ dozunda en fazla tutunmanın gerçekleştiği daha fazla dozlarda ise tutunmanın daha az olduğu tespit edilmişstir.

Sonuç olarak; perlit ortamına katılan sabit miktardaki vermikomposta ilave edilen artan miktarlardaki fosfor ve potasyum elementlerinin ortamda tutunmaları incelendiğinde; toplam 6 yıkama sonunda düzenli olarak ortama katılan miktarlar arttıkça her iki elementin de yıkanan miktarlarında artış olduğu belirlenmiştir. Ancak, yıkanarak ortamdan uzaklaşan miktarlar, ortamda bulunan toplam elementin \% değeri olarak incelendiğinde; 8 ve $12 \mathrm{~kg} \mathrm{P}_{2} \mathrm{O}_{5} / \mathrm{kg}$ dozlarında toplam suda çözünebilir fosforun sırası ile \%32.5 ve \%32.2 oranında yıkanarak en az yıkanmanın dolayısı ile en fazla tutunmanın gerçekleştiği saptanmıştır. Potasyumun ise $10 \mathrm{~kg} \mathrm{~K}_{2} \mathrm{O} / \mathrm{da}$ dozunda toplam suda çözünebilir potasyumun\%43.9'un yıkandığı ve en fazla tutunmanın bu dozda gerçekleştiği tespit edilmiştir.

\section{KAYNAKLAR}

[1] Adhami, E., Hosseini, S., Owliaie H. (2014). Forms of phosphorus of vermicompost produced from leaf compost and sheep dung enriched with rock phosphate. International Journal of Recycling of Organic Waste in Agriculture, 3, 68. doi:10.1007/s40093-014-0068-9

[2] Aria, M.M., Lakzian, A., Haghnia, G.H., Berenji A.R., Besharati H., Fotovat A. (2010). Effect of Thiobacillus, sulfur, and vermicompost on the water-soluble phosphorus of hard rock phosphate. Bioresource Technology, 101(2), 551-554. doi:10.1016/j.biortech.2009.07.093

[3] Ashley, M.K., Grant, M., Grabov, A. (2006). Plant responses to potassium deficiencies: a role for potassium transport proteins. Journal of Experimental Botany, 57(2), 425-436. doi:10.1093/jxb/erj034

[4] Bellitürk, K., Görres, J.H. (2012). Balancing vermicomposting benefits with conservation of soil and ecosystems at risk of earhworm invasions. $8^{\text {th }}$ International Soil Science Congress on "Land Degradataion and Challenges in Sustainable Soil Management", İzmir.

[5] Bilen, S., Sezen, Y. (1993). Toprak reaksiyonunun bitki besin elementleri elverişliliği üzerine etkisi 1. Azot, Fosfor ve Potasyum. Atatürk Üniversitesi, Ziraat Fakültesi Dergisi, 24 (2), 156-166. 
[6] Ceylan, Ş., Kılınç, R., Karakaş, D. (2013). Bitlis yöresi topraklarının fosfor adsorpsiyon ve fiksasyon durumlarının nükleer yöntem ile belirlenmesi. Ege Üniversitesi, Ziraat Fakültesi Dergisi, 40(1), 71-78.

[7] Denli, N. (2015). Marul Yetiştiriciliği. T.C. Gıda, Tarım ve Hayvancılık Bakanlığı, Tarımsal Araştırmalar ve Politikalar Genel Müdürlüğü, Alata Bahçe Kültürleri Araştırma Enstitüsü, Erdemli-Mersin.

[8] Edwards, C. A., Bohlen, P.J. (1996). Biology and Ecology of Earthworms (Third Edition). Published by Chapman and Hall, 2-6 Baundary Roww, London SE1 8HN, UK.

[9] Güllap, M.K., Erkovan, H.İ., Daşcı, M., Koç, A., Alatürk, F. (2009). Fosforlu gübre ve fosfor çözücü bakteri (Bacillus megaterium var. Phosphaticum )uygulamalarının çayırların verim ve botanik kompozisyonuna etkisi. Türkiye VIII. Tarla Bitkileri Kongresi, Hatay.

[10] Güzel, N., Gülüt, Y.K., Büyük, G. (2002). Toprak Verimliliği ve Gübreler. Çukurova Üniversitesi, Ziraat Fakültesi Genel Yayınları No: 246, Ders Kitapları Yayın No: 80, Adana.

[11] Jalali, M. (2011). Comparison of potassium release of organic residues in five calcareous soils of western Iran in laboratory incubation test. Arid Land Research and Management, 25, 101-115. doi:10.1080/15324982.2011.554957

[12] Korkmaz, K., İbrikçi, H. (2010). Kireçli topraklarda fosfor dinamiğinin belirlenmesi. Anadolu Tarım Bilim. Derg. (Anadolu J. Agric. Sci.), 25(1), 44-52.

[13] Mtua, K.A., Gökmen, Yılmaz, F., Gezgin, S. (2015). Artan dozlarda TKİ-Hümas ve fosfor uygulamaların kuru fasulye (Phaseolus vulgaris L.) bitkisinin gelişimine etkileri. Selçuk Tarım Bilimleri Dergisi, 2(2), 8490 .

[14] Müftüoğlu, N.M., Türkmen C., Çıkılı Y. (2014). Toprak ve Bitkide Verimlilik Analizler (2. Basım). Nobel Akademik Yayıncılık, Ankara.

[15] Najafi-Ghiri, M. (2014). Effects of zeolite and vermicompost applications on potassium release from calcareous soils. Soil and Water Res., 9, 31-37. doi:10.17721/2012-SWR

[16] Pramanik, P., Bhattacharya, S., Bhattacharyya, P., Banik, P. (2009). Phosphorous solubilization from rock phosphate in presence of vermicomposts in Aqualfs. Geoderma 152(1-2), 16-22. doi:10.1016/j.geoderma.2009.05.013

[17] Rodriguez, F., Guerrero, C., Moral, R., Ayguade, H., Mataix-Beneyto, J. (2005). Effects of composted and non-composted solid phase of pig slurry on N, P, and K contents in two mediterranean soils. Communications in Soil Science and Plant Analysis, 36(4-6), 635-47. doi:10.1081/CSS-200043305

[18] Sezen, Y. (1989). Van Gölü Çevresi Toprak Örneklerinde Islatma ve Kurutma ile Potasyum Fiksasyonu. Atatürk Ü. Zir. Fak. Der. 20(1), 18-29.

[19] Sönmez, S., Çıtak, S., Koçak, F., Yaşin, S. (2011). Vermikompost ve ahır gübresi uygulamalarının 1spanak (Spinacia oleracea var. L.) bitkisinin gelişimi ve toprak verimliliği üzerine etkileri. Batı Akdeniz Tarımsal Araştırma Enstitüsü Derim Dergisi, 28 (1), 56-69.

[20] Szczerba, M.W., Britto, D.T., Balkos, K.D., Kronzucker, H.J. (2008). Alleviation of rapid, futile ammonium cycling at the plasma membrane by potassium reveals $\mathrm{K}^{+}$-sensitive and-insensitive components of $\mathrm{NH}_{4}{ }^{+}$transport. Journal of Experimental Botany, 59(2), 303-313. doi:10.1093/jxb/erm309

[21] Şimşek-Erşahin, Y. (2007). Vermikompost ürünlerinin eldesi ve tarımsal üretimde kullanım alternatifleri. Gaziosmanpaşa Üniversitesi, Ziraat Fakültesi Dergisi, 24 (2), 99-107. 


\section{BŞEÜ Fen Bilimleri Dergisi}

7(2), 670-679, 2020

BSEU Journal of Science

DOI: 10.35193/bseufbd.658500

[22] Yağmur, B., Eşiyok, D. (2013). Solucan gübresi: vermikompost-III (Vermikompostun Kullanım Alanları) http://www.dunyagida.com.tr/haber/solucan-gubresi-vermikompost-iiivermikompostun-kullanimalanlari/4341 (Erişim tarihi: 15.03.2019).

[23] Yılmaz, E., Özen, N., Özen, M.Ö. (2016). Determination of changes in yield and quality of tomato seedlings (Solanum lycopersicon cv. Sedef F1) in different soilless growing media. Mediterranean Agricultural Sciences, 30(2), 163-168.

[24] Yurdakul, İ., Usta, S. (2017). Toprak organik maddesi ile fosfor adsorbsiyonu arasındaki ilişkinin Langmuir modeli ile araştırılması. Toprak-Su Dergisi, 6(2), 59-70. doi:10.21657/topraksu.339839 